\title{
Architectural Profession and its Role Towards the Design of Administrative Architecture in Malaysia
}

\author{
Hazrina Haja Bava Mohidin ${ }^{1}$, Asrul Aminuddin ${ }^{2}$, Aulia Rosni ${ }^{3}$, Eka Sediadi ${ }^{4}$ \& Farhana Mohd \\ Razif $^{5}$ \\ 1,2,3 SUPRE, Faculty of Built Environment, University of Malaya, 50603 Kuala Lumpur, Malaysia \\ ${ }^{4}$ Architecture Department, School of Engineering, American University of Ras Al Khaimah, (AURAK) \\ Ras Al Khaimah United Arab Emirates (UAE) \\ ${ }^{5}$ School of Housing, Building and Planning, Universiti Sains Malaysia,11800 USM, Penang, Malaysia
}

$\underline{\text { hazrinahaja@um.edu.my }}{ }^{{ }^{*}}$, asrulmahjuddin@um.edu.my $^{2}$, nurauliarosni@um.edu.my $^{3}$, eka.sediadi@aurak.ac.ae ${ }^{4}$,farhanarazif@usm.my ${ }^{5}$

Received: $28^{\text {th }}$ November $2019 \quad$ Final version received:28 ${ }^{\text {th }}$ December 2019

The paper aims to discuss the role of architects in the evolution of three main formal administrative architectures in Malaysia. All these three chosen case studies housed the main seat of the government of the era. The main concern is to outline the evolution of the administrative architecture in Malaysia through understanding the factors that may influence the production of these national buildings. A case study approach as defined by Yin (2011) was applied by using interpretivist approach in order to understand the factors that may have influenced the design of these prominent administrative architecture in Malaysia. The research shows there is a significant tie between the architect as part of the decision-maker and the design of the administrative building, making the selection of the architects for the purpose of building an important national architecture very important. To date, the research on the administration building in Malaysia focuses on design aspects, and none discussed the relationship between the administrative buildings with the architects' background with reference to societal conditions. The research is of value for clients as patrons of national projects to understand the syntax of 'administrative architecture' as these buildings are deemed as meaningful national symbols.

Keywords: Administrative architecture, national building, national symbols, national identity, architecture style.

\section{INTRODUCTION}

A government administrative architecture is a particular type of building that accommodates the work of administrators despite their levels and houses the office of the government's lawmakers (Vale, 2014). There is a wide range of known administrative architecture that is available throughout the world. At the national level, an administrative architecture is purposely built to show its power and status in the society, apart from serving as a building to run the seat of the government (Dovey, 2014; Minkenberg, 2014; Markus, 2013; Roberts, 2009). Like any other form of architecture, administrative building carries a wide selection of vocabulary especially in the subject of styles and from where these styles are being adapted (Mohidin et al., 2012). Past studies have found out that the design of administrative architecture is highly linked with the political background of the country (Mohidin, 2015; Mohidin \& Ismail, 2014; Mohidin et al., 2012), but none has discussed the role of the architects who were involved in shaping these prominent national symbols. Therefore, this study tries to link the relationship between the administrative architecture with the architects who were involved in the design and construction processes of these national administrative buildings. This is because, the production of design is a result of the collaboration between the designer/architect with the user/client (Norouzi, et al., 2015) in the process of designing a building, hence, it is seen crucial that the study elucidate on the involvement of the architect in shaping the national identity through the design of administrative architecture so as to avoid misconception of future national buildings. The 
study will be looking at case studies of administrative architecture built during the late British era; as these were the era when architecture began to be formalized, until the current era.

This study is important because the present state administrative architecture portrays pastiche architectural style instead of referring to the country's national identity and regional values. This study is essential in two meaningful ways. First, practicing architects and designers will be able to understand that the present and existing examples of administrative architecture may not necessarily be the best example of administrative architecture to symbolize Malaysia as a multiracial society and a democratic country. Second, this paper will provide a challenging perspective, particularly for architects and designers to make a concerted effort to study politics and the cultural context in which the built form is to be placed on site before proceeding to the design stage. This includes the need to probe into the dynamics of the relationship between built form and its society.

\section{ARCHITECTS ROLE AND PRACTICE IN BUILDING DESIGN}

Architecture as a profession deals with a wide range of processes, which includes planning, designing, managing, and coordinating the whole design practice (Norouzi et al., 2015). The role of the architect in a project is vital in creating the physical environment regardless of the building typology. The role of an architect in a project that involves political agenda plays an even important role, as the building will be a display of a nationalistic sentiment (Mohidin, 2015; Rasdi, 2005). This phenomenon often occurred in many modern states throughout the world due to the uprising of political regimes, since they greatly relied on symbols in the form of architecture, rituals, ceremonies, and displays to project the idea of legitimation (Sudjic, 2011). By arousing the nationalistic emotions of the masses and maneuvering the populace sentiments, they aim to maintain their status and position in society. Hence the engagement of the architect is crucial in shaping the image of national identity (Rasdi, 2005).

As administrative architecture is purposely built to show its power and status in the society, apart from serving as a building to run the seat of the government (Vale, 2014; Markus, 2013), it is worthwhile to discuss the evolution of architecture profession in light of the political climate of the country.

\subsection{Evolution of the Architecture Profession in Malaysia}

In Malaysia, the architecture profession only began formally during the colonial era. In the beginning, architecture activities were executed and supervised by British architects brought in by the British government (Hussain, 2015). It was in the late 1920s that the British government expanded its development programs and they needed a broader governing body to oversee the constructions in other states of Malaya (Hussain, 2015). In 1949, the Federation of Malaya Society of Architects (FMSA) was established and more initiatives regarding the architecture profession were introduced (Ngiom, 2013). The committee of FMSA was composed of architects who were trained in Britain and were members of the Royal Institute of British Architects (RIBA) (Hussain, 2015). Most of these architects once served in the Crown Colony, which was based in Calcutta India, but was placed directly under the control of the Colonial Office in London and were sent to Malaya to develop the new administrative settlements (Mohidin, 2012). They were placed in the Public Works Department (PWD) to manage projects ranging from housing, schools and government buildings (Shennan, 2015; Mohidin et al., 2012; Kien, 2007). After gaining independence, several members of FMSA went back to their countries and handed their posts to local architects who have trained abroad particularly Australia and the United Kingdom, and came back after completing their studies. (Hussain, 2017 \& 2015; Chun et al., 2005). This marked the beginning of the involvement of local architects in FMSA (Hussain, 2017 \& 2015; Ngiom, 2013) which later was named as The Malaysian Institution of Architects (PAM) in 1967 (Hussain, 2017; Ngiom, 2013). Though Malaya maintained some of the services of these British architects in the PWD office, there were more and more of local architects involved in building the nation (Chun et al., 2005). "They brought with them knowledge and experience which they gained abroad such as standardization and modularization of materials, design and building processes, together with the application of modern products and systems" (Hussain, 2017). In recent years, the architecture profession in Malaysia has evolved tremendously, with more 
local architecture schools established over the years, witnessing more local architects in service of their own country (Mohidin et al., 2012; Chun et al., 2005).

The gradual changing environment of the profession gave a significant impact as to how the building is being planned and designed. The involvement of the architects will be discussed further in the findings of this study.

\subsection{Evolution of the Architecture Profession in Malaysia}

\section{a. Pre-independence era}

The landscape of administration in the country went through a tremendous change during the British colonial rule; from being traditional to formal (Mohidin, 2012, Chun et al., 2005). When Malaya was under British colonial rule, the administrative buildings were one of the first building that was planned to be erected (Hussain, 2017; Goh and Liauw, 2009; Chun et al., 2005) with western designs and western technology in construction with a mix and match kind of outlook.

This was caused by integration among races as well as European culture that merged with the local people. It is undoubtedly that the building built during the colonial era tried to adopt certain aspects of local design such as the façade, form, as well as materials even when these buildings had unique characteristics that were foreign to the local culture. British colonial era saw a combination of architectural identity assimilated in a single building. This can be seen from the then newly built government buildings that tried to combine Malay architecture with traces of foreign architecture (Hussain, 2017; Mohidin, 2015; Chun et al., 2005)

\section{b. Post-independence Era}

During the first decade after independence, Malaysia still had colonial forces embedded within the system and their way of thinking. Administrative architecture during those times had foreign approaches in design. This includes ideas from the famous modernist architect in the west such as Le Corbusier, Frank Lloyd Wright and a few others (Chun et al., 2005). Adaptation of new technology and mechanism had penetrated into the designs of government administrative buildings and other massive projects like the railway stations.

The new government of Malaysia was in search of a new vocabulary for the architecture that can resemble the national identity and with this effort, most of the government building had a modernistic approach apart from being constructivist and had metaphoric expressions in them (Mohidin, 2012). The idea of uniting the races and community in the country had resulted in administrative architecture as well. Architectural elements that suited the local condition were famously adapted and incorporated into governmental buildings during this era as a symbol of nationalism (Mohidin, 2015).

As Malaysia progress into a well-developed country, new sentiment and political agenda fall into place wherein the case of administrative architecture, the design now had a new order and was more open, irony to the previous era where the agenda of the dominant group within a plural society was kept hidden. Establishing itself as an economically and politically stable country, Malaysia is now more vocal in voicing out what the country really wants to be seen as; MalayMuslim polity.

Administrative buildings played the role in voicing this agenda aloud as it is the most suitable building to describe the government as a whole. It is clear as to how our political leaders wanted Malaysia to be seen in the eyes of the world through the new Federal administrative city. The design of this new city, Putrajaya had a foreign architecture vocabulary, revivalism of a once very glorious political structure from the Middle Eastern countries, brainchild by the political leaders. 


\section{METHODOLOGY}

Using interpretivist approach, this study uses a multiple case study method as outlined by Yin (2011). This research will undergo direct observation as its data collection method and research strategy. The data is collected in two ways, i) observation of building form and façade and ii) understanding its background context as part of a design phenomenon. The framework of the study is as follows:

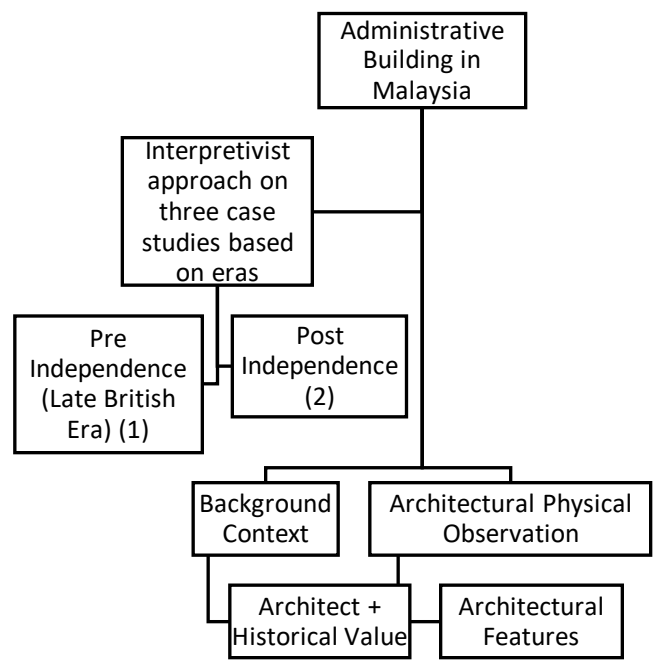

Figure 1 Methodology Framework

Since this paper involves the investigation of interpreting on the building design to produce a specific understanding, interpretivism too is seen as an appropriate way for inquiring this study as the aim of the paper is to interpret the meaningful nature and concepts that are embodied in the built form (Groat and Wang, 2013). Interpretivist approach expresses the researcher experience and through interpreting setting and events (Yanow and Schwartz-Shea, 2015). This is vital in order to understand the building that is bound to a specific context and setting. This is because interpretivism accepts that the investigator and the investigated object are interactively dynamically linked (Groat and Wang, 2013; Denzin and Lincoln, 2008). For the purpose of this study, three administrative buildings were chosen based on the historical timeline when architecture began to be formalized as tabulated below.

\begin{tabular}{|l|l|l|l|}
\hline \multicolumn{2}{|l|}{$\begin{array}{l}\text { Period of } \\
\text { governance }\end{array}$} & $\begin{array}{l}\text { Administrative } \\
\text { Architecture }\end{array}$ & $\begin{array}{l}\text { Functions during } \\
\text { Governance }\end{array}$ \\
\hline $\begin{array}{l}\text { Pre- } \\
\text { indepen } \\
\text { dence } \\
\text { Malaysia }\end{array}$ & $\begin{array}{l}\text { Late } \\
\text { British }\end{array}$ & $\begin{array}{l}\text { Sultan Abdul } \\
\text { Samad Building }\end{array}$ & $\begin{array}{l}\text { British colonial } \\
\text { administration }\end{array}$ \\
& $(1896-$ & & \\
\hline $\begin{array}{l}\text { Post- } \\
\text { indepen } \\
\text { dence }\end{array}$ & $1957)$ & & \\
Malaysia & $1957-$ & Parliament & $\begin{array}{l}\text { Legislative } \\
\text { complex }\end{array}$ \\
\cline { 2 - 4 } & 1970 & House & $\begin{array}{l}\text { Prime Minister's } \\
\text { Office }\end{array}$ \\
\hline
\end{tabular}

\section{FINDINGS - ARCHITECTURE AS A SYMBOL OF NATIONAL IDENTITY}

\subsection{Pre Independent Malaysia - The Late British Era Sultan Abdul Samad Building}

The administrative building during the British era reflects western designs and technology in construction with an assimilated outlook. These buildings had unique characteristics that were foreign to the local culture. British administrative had three phases of the era (Mohidin, 2014; 2015). They are; Straits Settlement, the Federated Malay States and the Non-Federated Malay States. The British begun to settle in Malaya in year the 1786 when the Sultan of Kedah agreed to allow the British East India Company to build a trading post and to operate in Kedah in favor of protecting the Kedah state from external threats. When the British developed the Strait Settlements, they built necessary buildings such as administrative buildings, churches, schools, shops and other institutional buildings (Kien, 2007; Chun et al., 2005).

British invasion continued and they conquered the Non-Federated Malay States after signing the Pangkor Treaty in 1884. During the early 21st century, they managed to surmount The Federated Malay States. This era witnessed rapid development in the local built environment context.

In the late era of their administrative period, the colonials built huge numbers of monumental structures across the country. This includes the Sultan Abdul Samad building which was the capital of British administrative center from 1896 onwards once Kuala Lumpur was declared as the capital town of Malaya. The building was 
designed by British architects A.C. Norman; R. A. J. Bidwell and A.B. Hubback who served in India for a number of years under the British Colony (Yi and Ahmad, 2017).

The Anglo-India style consists of two main features; Moghul architecture and the classical renaissance architecture. The Sultan Abdul Samad building was the capital of the British administrative center from 1896 onwards once Kuala Lumpur was declared as the capital town of Malaya.

The building has three copper onion domes that marked the Moghul style of architecture. The built form is monumental in scale, vertical in height or horizontally massive compared to human proportions and other surroundings. The façade comprised of arches of different patterns such as the pointed arch, ogre arch, horseshoe arch, multi-foiled arch and four-centered arch punching through a red-bricked wall. It is richly decorated with floral finials, embellishments and sculptural elements arranged in a hierarchical organisation at the roof, body and base section. The façade also has a distinct focal point that ideally projects a strong central focus decorated with the center tower equipped with a tower clock and the other two side towers are decorated with arches in a spiral motion, enhancing the overall perceptual stability. This arrangement provides a symmetrical axis and order while adding an element of interest to the bland monotonous façade. The placement of the building is strategically placed in an open ground facing a large square intending it to be noticeable and recognized to signify importance.

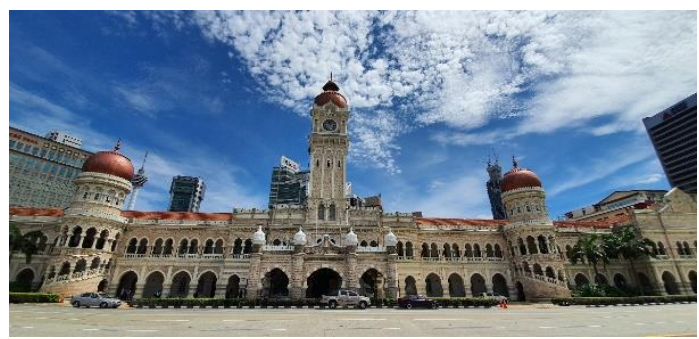

Figure 2: Sultan Abdul Samad Building (Source: Authors)

\subsection{Independent Malaysia - The Parliament House and Perdana Putra}

After achieving independence in 1957, the ruling of Malaysia is based on the federal representative democratic constitutional monarchy framework. The federal government has three main branches; the legislative, executive and judiciary. In Malaysian practice, more power is vested in the executive branch of government than in the legislative and judiciary. The early years after independence portrayed political agenda that much focuses on nation-building and national progress. During these periods, the leaders' main intention, strategies, and actions were to unite all races and religions in the country while maintaining the importance of Malay culture and Islam as the main religion.

For that reason, the country's building scene evokes nationalistic sentiments among the masses due to the representation of the national identity image. Such a prominent example is the Parliament building designed by British architect; Sir Ivor Shipley in 1962 (Mohidin, 2015; Kien, 2007). To project the Parliament building as a structure that upholds the principles of democracy for both the newly independent state and the populace - its design thus displayed no allusion to any ethnicity or of the dominant ethnic group.

The style adopted by the newly independent government in developing the country was a style that resembled all the races and religions in Malaya and is said to be the symbol of democracy of the government. For a modernistic building such as the Parliament House of Malaysia, it is clearly seen that the architectural language had changed tremendously as compared to the previous eras. This is due to the changing hands of the government from being colonized to an independent country. The building built after the year 1957, shows little or no trace of historic revivalism characteristics in its design.

It exhibits modernistic and progressive expression, which referred to local climatic conditions and regional values as well as the exploitation of contemporary materials and the latest available technology (Kien, 2007). The Parliament House of Malaysia bears a modernistic expressionist style ready to be translated by the society. The Parliament House has two parts; the main building and the tower 
building. The main building has a Malaccan traditional Malay roof style that definitely defined the Malay architecture. The tower emphasized more on the adaptation of the building towards the surrounding where the façade is being set back to shade the interior from direct sunlight. It carries no racial reference at all and being the taller and more dominant part of the building, it emphasized more on the adaptation of the building towards the surrounding where the façade is being set back probably to shade the interior from direct sunlight. New mechanisms were utilized during that era where steel frames are adapted into its structural system. The Parliament building blends in with the surrounding context and not arranged in a hierarchical manner with widescale base or high scale tapered roof (Mohidin, 2015).

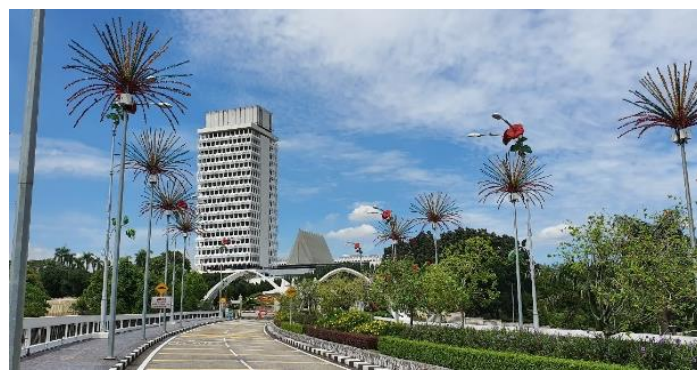

Figure 3: The Parliament House, Malaysia

(Source: Authors)

In the early era of 20th century Malaysia portrayed different political intentions and strategies, unlike previous years. This is because the country's administration much focused on the positioning of the Malay race and the Islamic religion as integral parts of the nation-building process besides placing high interest on the aspect of economic and social development. This nation-building program do not only involve the erection of the public but also government buildings throughout the nation. One of them is Malaysia's new administrative capital; Putrajaya.

Putrajaya, the new Federal Administrative Center has its highest administrative building that houses the office of the Prime Minister named Perdana Putra. The Perdana Putra has a distinctive feature that adopts foreign Revivalism in style. The scale of the Putrajaya project was grandiose and the most prominent building located at the Putrajaya Government Precinct (Precinct 1) is the Perdana Putra that houses the prime minister's office which was designed by a local architect; Ahmad Rozi Abd Wahab
(Mohidin, 2015). Completed in the year 1997, the architectural style of this building reflects the Indo Saracenic design approach. Perdana Putra is built on stone cladding walls that go up to about 50 meters in height and had a mix of architectural language where the pitched roof and the domes are being used to give the strongest character to the building (Mohidin, 2015). Nevertheless, the more appealing feature is the large green onion dome and also smaller domes that give a reflection of Arabic and Islamic character on its surface. The building also has smaller domes surrounding the building. The façade of the building is classically designed with the use of columns and arches and topped with the classical ornamented cornice slightly below the roofline imitating the Roman temples.

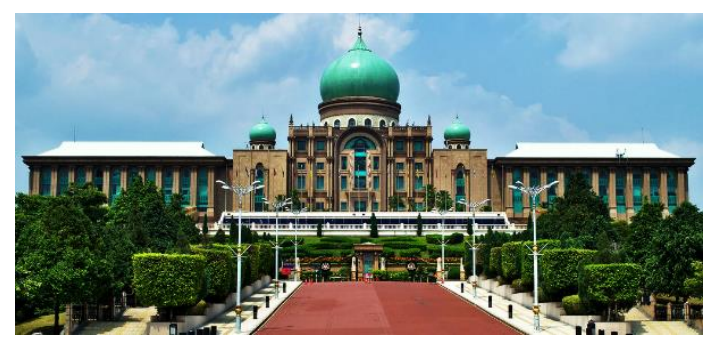

Figure 4: Perdana Putra (Source: Authors)

\section{DISCUSSION i. Sultan Abdul Samad Building}

The design of the building was perhaps due to the architectural background of the architect whom we know were British architects working in the Public Works Department. Apart from that, it is a known fact that the British had a long stay in India and being there for such a long time has influenced their thinking and their architectural expression. Nonetheless, during this time, the British government was trying to gain the hearts of the people in Malaya and one of the ways to do it is to emphasize the Islamic elements in architecture. It is being observed that there is a tendency that the westerners adopted Islamic architecture as a source of inspiration (Kurniawan and Kusumawardhani, 2012) in trying to engage the colony with the local people, which is seen not only apparent in Malaysia, but also in other parts of the world being colonized by foreign influences. This is also mostly seen on monumental buildings built during their time of governance (Kurniawan and Kusumawardhani, 2012). Another reason was probably due to the emergence of Indian merchants to Malaya who 
had commercial powers at that time and this may result in the design preferences of the administrative building during this era.

\section{ii. The Parliament House}

Based on the design of the Parliament House building, it is interpreted that the building portrayed a nationalist architecture vocabulary. This is due to the government agenda of that era where it is their goal to achieve racial unity while maintaining the dominant race that is the Malays. The design had a modernistic touch due to the architectural background of the building where the architect that was responsible for the design of the building is Sir William Ivor Shipley who was trained in Britain and went to India to study the Chandigarh designed by Le Corbusier with a modernistic characteristic. Imitating this idea, therefore it is natural for the Parliament to have both modernistic expressionism style in its design.

\section{iii. Perdana Putra}

Though the Perdana Putra was designed by a local architect, the building is greatly influenced by glorious eras in the past like the Islamic civilization and Western civilization. This is to signify that the government is symbolically as glorious as past eras and to show the advancement of the administrative system as well as its social and economic status of the country. It is clear as to how the design was manipulated in order for Malaysia to be seen in the eyes of the world through the federal administrative building. The design of Putrajaya had a foreign architecture vocabulary, revivalism of a once very glorious political structure from the Middle Eastern countries.

It is clear that historical development fostered different types of administrative buildings and the three main examples of administrative architecture in Malaysia each have their own unique characteristics tied back to its historical value and the architects who were involved in the design process of these buildings. Below is the summary of the study:

Table 2 - A comparative study of all three administrative architecture

\begin{tabular}{|c|c|c|c|c|c|}
\hline \multirow{2}{*}{$\begin{array}{l}\text { Administrative } \\
\text { Architecture }\end{array}$} & \multicolumn{3}{|c|}{ Background Context } & \multicolumn{2}{|c|}{ Architectural Physical Observation } \\
\hline & $\begin{array}{l}\text { Year } \\
\text { built }\end{array}$ & Historical value & Architect & Architecture features & $\begin{array}{l}\text { Building style } \\
\text { and influence }\end{array}$ \\
\hline $\begin{array}{ll}\text { Sultan } & \text { Abdul } \\
\text { Samad } & \end{array}$ & $1890 \mathrm{~s}$ & $\begin{array}{l}\text { Late British era } \\
-\quad \text { colonial } \\
\text { influences }\end{array}$ & $\begin{array}{l}\text { British } \\
\text { Architects }\end{array}$ & $\begin{array}{l}\text { Design brought in by } \\
\text { colonial rule emphasizing } \\
\text { on political and commercial } \\
\text { influences }\end{array}$ & Indo Saracenic \\
\hline $\begin{array}{l}\text { Parliament } \\
\text { House }\end{array}$ & 1960s & $\begin{array}{l}\text { Post- } \\
\text { independence } \\
\text { era - in search } \\
\text { of the right } \\
\text { identity as } \\
\text { progressing } \\
\text { nation }\end{array}$ & $\begin{array}{l}\text { British } \\
\text { Architect }\end{array}$ & $\begin{array}{l}\text { administrative } \quad \text { complex } \\
\text { construct as a resurgence of } \\
\text { nationalism or national } \\
\text { identity }\end{array}$ & $\begin{array}{l}\text { Modern } \\
\text { Expressionist }\end{array}$ \\
\hline Perdana Putra & 1990s & $\begin{array}{l}\text { Post- } \\
\text { independence } \\
\text { era } \\
\text { advancement in } \\
\text { administrative } \\
\text { systems }\end{array}$ & $\begin{array}{l}\text { Local } \\
\text { Architect }\end{array}$ & $\begin{array}{l}\text { Post-independence } \\
\text { advancement in polity - } \\
\text { government trying to } \\
\text { portrait new established } \\
\text { political agenda }\end{array}$ & Revivalism \\
\hline
\end{tabular}


It is true that architecture is always seen as a tool to convey political ideology as Vale (2014) has said, "Works of architecture become the major focus for political leaders to render their national ideologies. Architecture is the best tool as it metaphorically communicates to the masses through scale, form and other elements". This is also agreed by Askari (2009) in proving that the building façade is regarded as an important for the image making of the city. From the three case studies, it can be seen that the triangulation between architect - client/patron - societies exists substantially. Hence when the architect was engaged especially to design an administrative building for the government, as a professional, he needs to understand and get to know what the client wanted to emphasize in light of the societal conditions. The relationship of the architect - client/patron - society could not be separated as it is a fact that it is important for the patron to address the society while using architecture as the best way to communicate the political intentions.

\section{CONCLUSION}

In conclusion, it can be seen that the design of administrative architecture in Malaysia is greatly influenced by the background of professionals; the architect involved in the design process as well as the coexistence of political influences and the country's societal conditions. This includes the background of their training as well as the intended message to be delivered by the ruling body to the society who view the buildings. The architecture profession plays a major role in shaping the language of administrative architecture and could be more dominant in shaping most ideal image of national identity. Hence, architects should realize their role when being engaged in such an important project that deals with creating the image of the country as they are the medium through which the image of the country is being created. Ideally, this suggests that the architects aided in anticipating political empowerment through built form especially on the design of the main government building such as the administrative building. Hence, it is crucial for the architects to be aware of this role in order to send the right message to the mass populace especially through the design of its administrative architecture.

\section{REFERENCES}

Askari, A. H. (2009). Influence of building façade visual elements on its historical image: Case of Kuala Lumpur city, Malaysia. Journal of Design and Built Environment, 5(1).

Chun, H. K., Hasan, A. S., \& Noordin, N. M. (2005, September). An influence of colonial architecture to building styles and motifs in colonial cities in Malaysia. In 8th International Conference of the Asian Planning Schools Association.

De Rossi, A. (2011) Grande Scala: Architecture Politic Form. Italy:List- Laboratorio Editoriale

Denzin, N. K., \& Lincoln, Y. S. (2008). The landscape of qualitative research (Vol. 1). Sage.

Dovey, K. (2014). Framing places: mediating power in built form. Routledge.

Goh, B. L., \& Liauw, D. (2009). Post-colonial projects of a national culture: Kuala Lumpur and Putrajaya. City, 13(1), 71-79.

Groat, L. N., \& Wang, D. (2013). Architectural research methods. John Wiley \& Sons.

Hussain, N. H. (2017). Nation Building and Modern Architecture in Malaysia. Docomomo Journal, (57).

Hussain, N. H. (2015). Thoughts on Malaysian Architecture Identity and Design Principles of Malayan Architects Co-partnership (Doctoral dissertation, Universiti Teknologi Malaysia).

Idrus, A., Khamidi, F., \& Sodangi, M. (2010). Maintenance Management Framework For Conservation Of Heritage Buildings In Malaysia. Modern Applied Science, 4(11), 66.

Kien, L. C. (2007) Building Merdeka: Independence Architecture in Kuala Lumpur, 1957- 1966. Kuala Lumpur: Galeri Petronas.

Kien, L. C. (2015). Malaya in art and architecture. Inter-Asia Cultural Studies, 16(1), 113-127.

Markus, T. A. (2013). Buildings and Power: Freedom and Control in the Origin of Modern Building Types. Routledge

Kurniawana, K. R., \& Kusumawardhani, R. A. (2012). The influence of 19th century Dutch Colonial Orientalism in spreading Kubah (Islamic Dome) and Middle-Eastern architectural styles for mosques in Sumatra. 
Journal of Design and Built Environment, 11(1).

Minkenberg, M. (Ed.). (2014). Power and Architecture: The Construction Of Capitals And The Politics Of Space (Vol. 12). Berghahn Books.

Mohidin, H. H. B. (2015). Pengaruh Pemikiran Pemimpin Politik Terhadap Rekabentuk Senibina Pentadbiran di Malaysia (Doctoral dissertation, Universiti Teknologi Malaysia).

Mohidin, H. H. B., \& Ismail, A. S. (2014). Historical development of administration architecture in Malaysia (15th-21st century). In IOP Conference Series: Earth and Environmental Science (Vol. 18, No. 1, p. 012089). IOP Publishing.

Mohidin, H. H. B., Isa, N. M., \& Abdullah, A. M. Malaysian Administrative Architectural Trends 15th-21st Century: Learning From the Past To Shape The Future. Journal of Built Environment, Technology and Engineering

Mohidin, H. H. B., Ismail, A. S., \& Abdullah, A. M. (2012). A Study Of Styles Classification And Influences on Administration Building in Malaysia (15th-21st Century). In Seminar of International Convention: Bridging Between Old \& New.

Ngiom (Ed.) (2013). Malaysia's Architect, a History of PAM. The Malaysian Institute of Architects, KL: PAM

Norouzi, N., Shabak, M., Embi, M. R. B., \& Khan, T. H. (2015). A new insight into design approach with focus to architectclient relationship. Asian Social Science, 11(5), 108.

Rasdi, M. T. H. M. (2005). Malaysian architecture: Crisis within. Utusan Publications.

Roberts, S. (2009) Grand Designs: Parliamentary Architecture, Art and Accessibility. Political Science. 75-86

Shennan, M. (2015). Out in the Midday Sun: The British in Malaya 1880-1960. Monsoon Books.

Sudjic, D. (2011). The Edifice Complex: The architecture of power. Penguin UK.

Vale, L. (2014). Capital Architecture and National Identity. Power and Architecture: The Construction of Capital and the Politics of Space, 31-52.

Vale, L. (2014). Architecture, power and national identity. Routledge.
Yanow, D., \& Schwartz-Shea, P. (2015). Interpretation and method: Empirical research methods and the interpretive turn. Routledge.

Yi, L., \& Ahmad, Y. (2017) Design Influence of Mughal Architecture in Kuala Lumpur. Safeguarding Cultural Heritage: Challenges and Approaches, 49. 2nd International Nusantara Cultural Heritage Symposium 2017

Yin, R. K. (2011). Applications of case study research. Sage. 